\title{
Entrepreneurship Education as a Vital Tool for Wealth Creation and Unemployment Reduction in Nigeria
}

\author{
Tofi Simon Ternenge ${ }^{1}$, Obeta Mark Uchejeso ${ }^{2 *}$, Goyin Longul Philemon ${ }^{3}$ \\ ${ }^{1}$ Benue State School of Nursing, Makurdi-Nigeria \\ ${ }^{2,3}$ Department of Public Administraion and Local Government, University of Nigeria, Nsukka-Nigeria
}

\author{
Article History \\ Received: 17.05 .2020 \\ Accepted: 08.06.2020 \\ Published: 26.11.2020 \\ Journal homepage: \\ https://www.easpublisher.com
}



\begin{abstract}
The progress of a nation is a function of the level of the resourcefulness of the people which to a great extent, relates to the level of quality of the training and purposeful development of education in that nation. Such progress or development could only occur when an individual in the society is gainfully employed and per capital income is enhanced. This could only be possible when government educational policies are geared towards a functional education that can lead to job creation and also selfreliance. Entrepreneurship education is a means through which government could attain such development in the society. Therefore, this paper examined entrepreneurship education as the way forward to wealth creation and unemployment in Nigeria. Entrepreneurship education could help in wealth creation and graduates employment in Nigeria. Entrepreneurship education in Nigeria with effective implementation of the programme could help to overcome the challenge of unemployment.
\end{abstract}

Keywords: Entrepreneurship, Education, Wealth creation, Unemployment.

Copyright (C) 2020 The Author(s): This is an open-access article distributed under the terms of the Creative Commons Attribution 4.0 International License (CC BY-NC 4.0) which permits unrestricted use, distribution, and reproduction in any medium for non-commercial use provided the original author and source are credited.

\section{INTRODUCTION}

Unemployment as it is called has been an issue of discourse in Nigeria. The unemployment situation in Nigeria is disturbing and even more disheartening that the country's economic condition cannot absorb an optimal proportion of its labour force. Though unemployment is on the increase in Nigeria, Goyin et al. [1] reveals that there is presence of entrepreneurial activities in Plateau Central Senatorial Zone of Plateau State, Nigeria which are thriving.

In separate reports, the National Institute for Social Research (NISER) and the World Bank cited by Ezie [2] revealed that over 55 per cent of Nigerians of working age are unemployed, representing one in five adults. According to the author, the World Bank report also indicated that only one in every ten graduates get a job while a recent report by the National Directorate of Employment (NDE) indicated that over 200,000 Nigerian graduates who completed the National Youth Service Corps (NYSC) in the last five years, remained unemployed. The reason for this of course is obvious, Nigeria educational system that turns out graduates from about 150 Universities and 80 Polytechnics and Mono-technics have not trained our graduates to be self-reliant, but to depend solely on white collar-jobs for sustenance. As a result, there are several graduates from Nigerian Universities today who are not gainfully employed. Apart from the book knowledge that they gained there are no requisite skills to make them selfdependent.

Unemployment in Nigeria has affected the youth (graduates) and the economic development of the country from a broad spectrum of socio-economic perspective. It is obvious that the situation especially that of youth unemployment affected Nigeria's progress in several ways. Apart from the economic waste it brought to the nation, it also constitutes political unrest for the country [3]. This situation has also resulted in the continuous increase in crimes and other social vices experienced in our society in recent time. This has grown large that the situation cannot be addressed by mere campaign or words of mouth [4]. It requires the combined efforts of both individuals and the government of the country in particular and the world at large to formulate a lasting strategy to curb this menace. There is therefore the need to engage the unemployed graduates in meaningful engagement to avoid unhealthy alternatives for this group of people. This can be effectively carried out through the educational sector.

Education has always been canvassed as one of the most visible ways out of poverty but this assertion is becoming invalid with the increasing number of unemployed university graduates. It is now 
obvious that except the citizenry is exposed to the right education, unemployment would remain unabated. One of the ways of ensuring that education assists in addressing national and global unemployment is by incorporating entrepreneurship education into the curriculum.

Entrepreneurship education is a catalyst for economic development and job creation in any society and it involves rebranding the education culture to the end of guaranteeing a comprehensive educational system re-engineering arising from the obvious deficiencies of the existing educational system [5]. Entrepreneurship education's main focus is to provide the students with requisite skills and capacities needed in the world of work.

A broader definition of entrepreneurship education was provided by Obinna [6] as the process through which individuals acquire a broad set of competencies that can produce greater social and economic benefits to the individuals. According to Enu [2], Entrepreneurship education is a form of education that seeks to provide knowledge, skills, attitude and motivation to students for entrepreneurial success in any facet of human endeavours. The source further argues that entrepreneurship education equips individuals with the ability to seek investment opportunities and maximize returns from those investments.

Entrepreneurship Education is learning directed towards developing in people those skills, competencies, understanding and attributes which equip them to innovative and to identify, create, initiate, and successfully start and manage personal/or community business and seek for opportunities to change society for the better while working for themselves or organization [7]. Entrepreneurship education as part of the total educational system is the type of education that involves the acquisition of skills, ideas and management abilities necessary for job creation. An entrepreneur promotes employment rather than seeking for an employment. Therefore, there is a need to embrace this type of education and provide all the necessary resources needed to make functional. Quality entrepreneurship education could be used as a tool for fighting the war against poverty and unemployment in Nigeria. Education is said to be qualitative when the input such as students, teachers, finance, facilities and equipment and all these are converted through teaching and learning (theory and practical) and produce a desirable output. The output is better equipped to serve themselves and the society. The quality of input influences to a large extent the quality of output. In other words, the quality of the input of entrepreneurship education such as teachers, students and infrastructural facilities will influence greatly, the input of the output [8]. Therefore, quality entrepreneurship education will enhance job creation which will subsequently reduce unemployment, poverty and social vices in Nigeria. This will also help to improve the standard of living; hence promote social economic and political development in Nigeria which is the cardinal objective of Millennium Development Goals [9].

Henry [10], views entrepreneurship as the engine driving the economy of nations, creating new industries, young entrepreneurs, employments and wealth. Also in the view of Agbionu [11], entrepreneurship involves a process aimed at creating wealth for the purpose of growth, development of the environment and eradication of unemployment for national sustainability.

According to Wikipedia [12], wealth is the abundance of valuable resources or materials possessions. Basically, this means that an individual is considered wealthy if he has a lot of something that others value. Wealth creation is the process of building up valuable assets and resources for personal enrichment [13]. Wealth creation leads to a better quality of life and more individual autonomy. Wealth creation works best with a seed investment that will allow the individual investor to invest diversely and start accumulating funds for more investments. The wealth that is to be created (or income to be generated) by an entrepreneur is in the form of value added. That means something (valuable) already has some value, and our activities will add more value to it. That additional value is the wealth that is generated.

For the recipient of entrepreneurship education to be a job creator rather than job-seeker, he might acquire essential basic skills and attitudes which will enable him to function as an entrepreneur. Some of the skills as pointed out by Kalu [13] include; innovativeness, creative, imaginative, bold and persistent, alert to unnoticed opportunities, change initiator, intrinsically motivated, risk-taking propensity, growth ambitious, independent, and providing leadership.

Despite the relevance of entrepreneurship education for wealth creation and graduates employment in Nigeria, its full implementation is constrained by several challenges. Prominent among these challenges according to Nnadozie [14], are logistic problems, inadequate funding, and inadequacy of relevant teaching and learning support facilities, as well as shortage of qualified personnel to teach entrepreneurship studies in various educational institutions.

It is against this background that this paper, discuss entrepreneurship education as a vital tool for wealth creation and unemployment in Nigeria. 


\section{CONCEPTUAL CLARIFICATION}

In this paper, five major concepts are identified and clarified for better understanding of the subject matter. These include; entrepreneur, entrepreneurship, entrepreneurship education, wealth creation and unemployment.

1. Entrepreneur: entrepreneurs are persons who create some new events, organise factors of production, undertake risk and handle economic uncertainty involved in the new enterprise/ venture. They are persons who create an enterprise, search for change and respond to it. Sunday-Nwosu [15] opined that the entrepreneur is someone who creatively and innovatively starts a new business, and manages the business into profitable venture bearing the risks associated with it. $\mathrm{He}$ is an innovative person, an empire builder, a pathbreaker and a pacesetter of economic and industrial growth. An entrepreneur in essence, initiates enterprise creation, undertakes risks, and manages resources to establish and operate a business enterprise that is capable of self-sustenance.

2. Entrepreneurship: entrepreneurship is the willingness and ability of an individual to seek out investment opportunities, establish and run an enterprise successfully. Entrepreneurship is defined as the creation and running of one's own business. Esomomu cited by Asongwa and Dim [16] defined entrepreneurship as the effective manipulation of human intelligence, as demonstrated in a creative and innovative performance. The National Directorate of Employment (NDE) in Onyebueke and Ochnongo sees entrepreneurship to be an art which involves recognizing a business opportunity, mobilizing resources and persisting to exploit that opportunity. It is also the process of bringing together creative and innovative ideas and copying them with management and organizational skill in order to combine people, money and resources to meet an identified need and thereby creating wealth. It provides entrepreneurs with managerial, entrepreneurial and technical skills. Nwangwu [17] says it is a process of bringing together the factors of production which include land, labour and capital so as to provide a product or services for the public consumption. It is obvious from the above definitions that entrepreneurship is a set of skills an individual acquire that make him innovative, and capable of transforming the factors of production into something new, and which will be beneficial to the society, and at the same time bring monetary value to the individual.

3. Entrepreneurship Education: According to Enu [2], entrepreneurship education is a form of education that seeks to provide knowledge, skills, attitude and motivation to students for entrepreneurial success in any facet of human endeavours. The author further argues that entrepreneurship education equips individuals with the ability to seek investment opportunities and maximize returns from those investments. In essence, it provides the students with the knowledge, skills, and motivation needed to start up a small scale business.

4. Wealth Creation: wealth creation describes a situation of prosperity. Wealth means the possession of riches, the abundance of valuable resources or material possession. Adam smith cited by Horsfall [18] viewed wealth creation as the combination of materials, labour, land, and technology in such a way as to capture profit. Dada [19] states that wealth creation simply refers to economic growth and better standard of living of the individual, family, and state. The source further stated that wealth creation refers to two (2) concepts; "the coping strategies" and "empowerment". I shall be considering the empowerment concept for the purpose of this paper. According to him, empowerment concept is a process which gives people power over the different social, economic, cultural and political forces which govern their lives. The aim of empowerment is to create true wealth and involve the people in all aspects of governance. Any wealth creation initiative must boost the human capital element such as knowledge, skills and health which increase the total productivity of individuals and human development index of the society. Heller 2003 defines wealth creation in terms of income generation which is the creation of assets, both in terms of physical and human capital.

5. Unemployment: According to the Oxford advanced dictionary of current English [20], unemployment is defined as the state of not having a job. The source further stated that, unemployment is the fact of a number of people not having a job. In essence, it refers to the number of people without a job. It is a situation where people graduate from various higher institutions of learning without any meaningful employment. Umuaka cited by Ifeanacho and Ifeanacho [21] defined unemployment as not having any realistic means of livelihood, a state of not engaging in economic activities.

\section{Objectives of entrepreneurship education}

The objectives of entrepreneurship education clearly show that it is concerned with the development and survival of both the individual and society. In fact, it is a tool through which social, economic and political development could be achieved. If it is properly planned, funded and implemented. The objectives of entrepreneurship education are spelt out by Osuala [22] as:

1. To provide meaningful education for youth which could make them self-reliance and subsequently encourage them to drive profit and be self-independent. 
2. To provide graduate with the training and support necessary to help them establish a career in small and medium size business.

3. To provide graduates with training skills that will make them meet the manpower needs of the society.

4. To provide graduates with enough training in risk management to make uncertainty bearing possible and easy.

5. To improve business and organisational performance.

6. To stimulate industrial and economic growth of rural and less developed area.

7. To provide graduates enough training that will inspire creativity and innovation in identifying new business opportunities.

8. To provide small and medium sized companies with the opportunity to recruit qualified graduates who will receive training and tutoring in the skills relevant to management of the business centre.

9. To encourage movement of information, knowledge and creativity.

10. To inspire people to accept and respond/ adjust to change.

Entrepreneurship education also draws part of its justification from the concerns expressed by various stakeholders, especially, employers of labour over the poor quality of education. The desire to arrest the diminishing standard of education gave impetus to the introduction of entrepreneurship education. The idea is to enrich the learning experiences, as well as, expose the learner to business management skills, risk bearing, fund-raising and other elements of positive work ethics. Integration of these components of entrepreneurship education into the courses taken by students will radically improve the quality of education because the graduates would be exposed to valuable knowledge with which to survive in self-employment [14].

Entrepreneurship education according to Paul [23], stands also to achieve the following objectives: offers functional skills for the youth that will enable them to be self-employed and self-reliant; provide the youth graduates with adequate training that will enable them to be creative and innovative in identifying novel business opportunities; serve as a catalyst for economic growth and development; offer tertiary institution graduate with adequate training in risk management to make certain bearing feasible; reduce high rate of poverty; employment generation; provide the young graduates with enough training and support that will enable them to establish a career in small and medium size business; inculcate the spirit of perseverance in the youths and adults that will enable them to persist in any business venture they may embark on; and create smooth transition from traditional to a modern industrial economy.
From the above objectives, it is evident that this type of education if it is given all it deserves and properly implemented will produce quality graduates that will foster job creation and reduce or eliminate poverty in Nigeria. This could be realized when the graduates are self-reliant by establishing their own business small/medium scale enterprises. Job creation is one of the cardinal objectives of Millennium Development Goals. When an ample job opportunities is created it will invariably help to reduce poverty and unemployment and as well, enhance better standard of living of an individual through wealth creation in Nigeria.

\section{Benefits of entrepreneurship education}

Entrepreneurship education as the process of professional application of knowledge, attitude, skills and competences that involve creativity, innovation and risk taking.

According to Raposo and Paco [24], entrepreneurship education prepares the youths to be responsible and enterprising. In similar vein, UNESCO [25] viewed educational entrepreneurship as all kinds of experiences that give students the ability and vision of how to access and transform opportunities of different kinds. In essence, educational entrepreneurship provides a platform for youths to transform opportunities to business ventures and to manage those ventures to become a medium for job creation for themselves and others.

Entrepreneurship education, according to Ifeanacho and Ifeanacho [21] is of great benefits because; it raise awareness, change people's attitude towards entrepreneurship, it enable students know how economy works and getting more familiar with ideas to become an entrepreneur. Other benefits according to the authors include; development of critical thinking, personal initiative, making decision, taking responsibility and ability to learn. Similarly, Lundahl, Arreman, Lundstrom and Ronnberg cited by Kalu [13] include also the following as entrepreneurship educations benefits; preparing students to run their own enterprises, learn customer relations, provision of competence and competitiveness of trade, companies and individuals, provide young people with knowledge of how to start and develop business as well as developing in the students curiosity and desire to learn and offer a knowledge that will make both staff and students to reinforce or develop entrepreneurial ability.

To support this, Enu [2] argues that the ultimate goal of educational entrepreneurship is all about increasing the student's ability to anticipate and respond to societal changes. In other words, through educational entrepreneurship, students are equipped to deploy their creativity ability for their good and benefits of the larger society. They are also empowered to take initiatives, responsibilities and risks. Entrepreneurship 
education has been found to be a vital tool in addressing unemployment and wealth creation where policies are designed appropriately and effectively implemented. For instance, entrepreneurship education was observed by scholars like Álvaro et al., [11] and, Iyiola, and Azuh [26] to assist in creating new businesses, resuscitating challenged businesses and as well as encouraging innovations, competency and improving the standard of living of the generality of the people.

The inclusion of entrepreneurship education in the curriculum of tertiary institution is meant to increase the innovation and creativity level in students, so that at the end of their study in the institution they will be able to provide for themselves a means of living, create job opportunities for others, add value to the life and their communities and also, assist in the development of their nation.

Having been successfully equipped with entrepreneurial skills through persistent education, one is ready to contribute positively in reducing unemployment by being self-employed. Entrepreneurship education stands out to be an antidote to unemployment having worked in line with today's educational policies that highlight self- reliance, selfemployment, gainful employment and also consistent with the global awareness. Entrepreneurship education enhances the acquisition of necessary skills for gainful and self-employment. As a specialized training given to students to acquire skills, ideas and managerial abilities and capabilities for self-employment stands as a panacea to unemployment saga in Nigeria [27].

\section{Entrepreneurship education: how it could help in wealth creation and graduates employment}

Entrepreneurship Education plays a vital role in the social, political and economic development of any Nation. This is possible when jobs are created for the citizenry by establishing a lot of businesses that will accommodate the unemployed youth in Nigeria. A qualified graduate of entrepreneurship education would have acquired enough skills relevant to management of small business centre. Maina [28] highlighted the following as ways in which entrepreneurship education could help in wealth creation and reduce unemployment:

- Creation of self-employment: An entrepreneur provides job for himself by establishing small business centre. This will help to reduce the problem of unemployment and other social vices in Nigeria. The entrepreneur does not only provide jobs/employment for himself alone, but provides for others too. This in turn helps the individual to increase per capital income hence improve standard living.

- The Entrepreneur determines or identifies the specific wants of the people and the type of goods and services that will fulfil those wants most comfortable. Emeruwa [29] asserted that the entrepreneur does not only identifies but mobilizes and organizes the resources to tap the opportunities by assisting men, materials, money and machines to explore the opportunity.

- Production of goods and services that is important to the well-being, comfort and happiness of individuals in the society at large.

- Entrepreneurship stimulates rural, economic and industrial development. They contribute to the development of rural areas. They do this by establishing their small/medium scale enterprise in such areas by discouraging rural migration. They provide ample job opportunities to the rural dwellers. They also provide goods and services, which could be found in an urban area and sometimes provide infrastructural facilities.

- The entrepreneurs are usually motivated in their activities not only by the need for material contributions to the welfare of the communities but also desire to make profit. This uplifts the dignity of labour.

- Through entrepreneurship education, utilization of local resources is made possible. The graduates of this specialized education set up their small/ medium scale business, which will enable them to utilize the local resources available in their vicinity. The uses of local raw materials are discarded by products of large firms as primary input in their production processes. Owualah in Olorunmolu [11] asserted that in terms of their economic benefits small firms can be said to be greater in local resources maximizes than their large counterparts. The provision of raw materials for the big firms help them to increase their production hence employ more personnel thereby creating jobs for unemployed youth in the country.

- Through entrepreneurship education, a pool of potential entrepreneurs who are well equipped with skills and technical know how to manage small/medium scale industries are produced. This will equally help in job creation. Through quality entrepreneurship education, Nigeria could produce a lot of entrepreneurs who could establish and manage businesses on their own.

According to Sunday-Nwosu [15], entrepreneurs are today seen as the catalyst which speeds up the process of creating wealth for the economy, providing jobs and providing jobs and providing an assorted range of goods and services to the general masses. The source further highlight the relevance of entrepreneurship education as it leads to wealth creation in three perspectives as follows:

- Wealth creation and distribution: entrepreneurship education stimulates equitable redistribution of wealth and income in the interest of the country to more people and geographical areas, thus giving benefit to large sections of the society. 
- Creation of new jobs and wealth: provides employment to huge mass of graduates; entrepreneurship education leads nations towards better opportunities which is a significant input to an economy. It provides the most jobs in the country.

- Wealth creation for nation and for the individuals: all individuals who search for business opportunities usually create wealth by entering into entrepreneurship. The wealth created by the same, play a considerable role in the development of nation.

- Improvement in the standard of living: creation of wealth through entrepreneurship education leads to improvement in the standard of living of the people. Increase in the standard of living is a characteristic feature of economic development of a country. Entrepreneurs plays a key role in increasing the standard of living of the people by adoption of the latest innovation in the production of a wide variety of goods and services on a large scale that too at a lower cost. The enables the people to avail themselves of better quality goods at lower price which results in the improvement of standard of living.

Based on the above merits, it is no doubt that entrepreneurship education could be used as major weapon in achieving the Millennium Development Goals (MDGs) by empowering the individual in the society to be self- reliant. This will help in wealth creation and reduce the rate of unemployment in Nigeria.

\section{Challenges of enterpreneurship education in nigeria}

Entrepreneurship Education could played a vital role in equipping individual with necessary intellectual capacity, skills and right type of work habit and attitude to be able to create jobs for the growth of the Nigeria economy. However, what is quite essential is the extent to which the entrepreneurship education programme can be implemented to realize these goals. The programme is confronted with a lot of challenges which brought a setback in the attainment of its objectives. These challenges have not enable Nigerian to enjoy the benefits of this programme as expected. This limits the achievement of the millennium development goals (MDGs) in Nigeria.

Some of the challenges have been pointed out by eminent scholars such as Gana [9], Aiyeduso [30], Osuala [22], Goyin et al. [1] and they include:

1. Poor funding by government and Nongovernmental organizations.

2. Poor or ineffective planning, supervision, and evaluation of the programme across the board.

3. Inadequate teaching materials, equipment and infrastructural facilities.

4. The challenges posed on globalization, information and communication technology (ICT) have effect on curriculum, methodology, facilities, staff and equipment.

5. Shortage of competent resource persons to teach entrepreneurship studies in various educational institutions.

6. Inadequate motivation for available teaching and non-teaching staff which affects staff efficiency, retention, creativity and initiative.

7. Emphasis on theoretical Knowledge rather than practical knowledge due to lack of entrepreneurship education centre.

8. Housing of the course "Entrepreneurship studies" in higher institutions in Nigeria under the schools of general studies. Also, the period allotted to entrepreneurship education courses in the timetable is normally insufficient which negatively impact on the quality and depth of the lectures.

9. High level of corruption and very poor maintenance culture in the system.

10. Poor enabling business environment, access to credit/ loan, infrastructural decay, mass poverty, inflation, technological infraction, political instability and insecurity of lives and properties which hamper economic and business activities.

11. Lack of entrepreneurial education amongst others.

\section{CONCLUSION}

Since early 1980's, Nigeria has a history of economic stagnation that has led to decline in white collar jobs. The inclusion of entrepreneurship course in all disciplines will to a great extent, assist in solving this problems of high unemployment and underemployment. Entrepreneurship education in this paper has been recognized as a key driver in encouraging business start-up potentials among graduates. Since entrepreneurship education plays a vital role in unemployment reduction and support wealth creation, it becomes mandatory for all higher institutions to ensure full implementation of the programme and skill acquisition in training students not just in theory but in practice. If this is done, the challenge of unemployment of graduates in Nigeria will be reduced and as such leads to creation of wealth.

\section{RECOMMENDATIONS}

The following recommendations are proffered for effective entrepreneurship education in Nigeria.

1. The federal government in collaboration with state governments should provide scholarships/ bursaries for performing students by way of encouragement.

2. Employment of competent and qualified lecturers and teachers.

3. Government should establish entrepreneurship centres in different local government to enable graduates acquire the necessary training in entrepreneurship education. Also, the emphasis on the entrepreneurship training in these centres should be practically oriented.

4. There should be collaboration between small business entrepreneurs and research institution for 
exploitation and research findings of those institutions to achieve technology development.

5. Governments at all levels could intervene in postulating good policies to reduce the problems of entrepreneurs through the supply of needed technological and business information and advices.

6. The federal government of Nigeria should provide enabling environment conducive for the smooth operation of both indigenous entrepreneur and foreign investors in order to boost the economy.

7. Securities of life and properties, provision of infrastructural facilities like constant power supply, good road, good health care services, and drinkable water among others should be guarantee by the federal, states and local governments in Nigeria for better performance of entrepreneurs at reduced cost also to prevent them from migrating to neighbouring countries.

8. There is need for increased support for entrepreneurship education by strategic stake holders like the National Directorate of Employment (NDE), National Association of Small Scale Industries (NASSI), Nigerian Association of Chambers of Commerce, Industries, Mines, and Agriculture (NACCIMA), Federal Institute of Industrial Research, Oshodi (FIIRO), Raw Materials Research and Development Council (RMRDC), and Project Development Agency (PRODA), etc. these stakeholders are expected to collaborate with educational institutions by making their facilities available and assessable to students taking courses in entrepreneurship studies.

\section{ACKNOWLEDGMENT}

Federal College of Education Obudu Alumni (FECOA), Benue State where the paper was presented at the 13th Anniversary, Award Presentation and End of Year Party of the students on Saturday 28th December, 2019 at Princess Adeja International College, GbokoBenue State, Nigeria.

\section{REFERENCES}

1. Goyin, L.P., Micah, G., \& Obeta, M.U. (2019). Entrepreneurship Development in Plateau Central Senatorial Zone of Plateau State, Nigeria (20112017). International Journal of Innovative Research \& Development, 8(9) 18-26. http://www.ijird.com DOI: $10.24940 / \mathrm{ijird} / 2019 / \mathrm{v} 8 / \mathrm{i} 9 / \mathrm{SEP} 19019$

2. Enu, D.B. (2012). Enhancing the Entrepreneurship Education in Nigeria. American Journal of Social Issues \& Humanities, 2(4): 232-239.

3. Igwe. (2013). Promoting wealth and job creation in Nigeria: Review of the role of entrepreneurship. Journal of Sustainable Development Studies, 3(1): 80-100.

4. Nwankwo, C. A., \& Ifejiofor, A. P. (2014). Impact of unemployment on Nigerian economic development: a study of selected local government area in Anambra State, Nigeria. European Journal of Business and Management, 6(35), 103-112.

5. Lee, L., \& Wong, P. K. (2004). Entrepreneurship education: A compendium of Related Issues. Retrieved from http://www.thefreelibrary.com

6. Onuaguluchi, O., \& Panesar, D. K. (2014). Hardened properties of concrete mixtures containing pre-coated crumb rubber and silica fume. Journal of Cleaner Production, 82, 125-131.

7. Ikeme, A.I. (2012). Readings in Entrepreneurship: Bridging learning and Earning: Grand-Heritage Global communication, Nsukka, Enugu State.

8. Olorunmolu, J. O. (2010). Entrepreneurship education in Nigeria: Prospects and challenges. Journal of management science and Technology Education, 4(1), 110-115.

9. Gana J. S. (2000). Entrepreneurship. Jos: Jofegan Associate Pub.

10. Poutanen, S. M., Low, D. E., Henry, B., Finkelstein, S., Rose, D., Green, K., \& Chan, A. K. (2003). Identification of severe acute respiratory syndrome in Canada. New England Journal of Medicine, 348(20), 1995-2005.

11. Agbionu, T. U. (2008). The Basics of Business Success: An Entrepreneurship Practical Approach. Lagos: Topline Publishers.

12. Agboola, I.A. (2019). Entrepreneurship education: The way forward to Job creation in Nigeria.

Retrieved from https://www.academia.edu/17215440/ENTREPRE NEURSHIP_EDUCATION_THE_WAY_FORWA RD_TO_JOB_CREATION_IN_NIGERIA

13. Kalu, I. (2014). Tertiary education for global competitiveness and entrepreneurship. International Journal of Educational Research, 13(1): 47-64.

14. Nnadozie, C. O. (2014). The concepts of entrepreneurship education: Justification for its teaching and learning in library and information science. In A.O. Issa, C.P. Uzeegbu, \& M.C. Nwosu (Eds). Entrepreneurship studies and practices in library and information science, (Pp.45-67). Umuahia: Zeh communications.

15. Sunday-Nwosu, C. (2015). Pathways to effective entrepreneurship: A complete guide to successful business. Lagos: GUZMAN Nig. Ltd.

16. Muthui, P., \& Mutweleli, S. M. Academic SelfEfficacy As A Predictor Of Academic Locus Of Control Among Secondary School Students In Kenya.

17. Nwagwu, I.O. (2007). Higher Education for SelfReliance: An Imperative for the Nigerian Economy. NEAP Publication.

18. Horsfall, M.N. (2017). Entrepreneurship and wealth creation as the game changer for unemployed graduates of library and information science. In N.E. Achebe \& A.J. Mole (Eds.). Global Best Practices in Library and Information Services in Contemporary Era, (pp. 71-78). Enugu: Praise House Publishers. 
19. Kazaz, B., Dada, M., \& Moskowitz, H. (2005). Global production planning under exchange-rate uncertainty. Management Science, 51(7), 11011119.

20. Hornby, A.S. (2015). Oxford Advanced Learners Dictionary of Current English. ( $9^{\text {th }}$ ed.). United Kingdom: Oxford University Press.

21. Ifeanacho, V.A. \& Ifeanacho, J.C. (2014). Secondary school entrepreneurship education: An imperative for entrepreneurship development, job creation, wealth generation and global competition. International Journal of Education Research, 13(1): 211-221.

22. Osuala, E.C. (2004). Principle and practice of small Business management in Nigeria: A Didactic Approach. Nsukka: Fulladu Publishers

23. Paul, E.O. (2005). Entrepreneurship education in vocational education. Enugu: OZYBEL publishers.

24. Raposo, M., \& Paco, A. (2011). Entrepreneurship education: Relationship between education and entrepreneurial activity. Psicothema, 23(3): 453457.
25. Alvaro C., Domingo, R., \& Salvador, R. (2008). Entrepreneurship: Concepts, Theory and Perspective. Introduction, Madrid: Universitat de València.

26. Iyiola, O., \& Azuh, D. E. (2014). Women entrepreneurs as small-medium enterprise (SME) operators and their roles in socio-economic development in Ota, Nigeria.

27. Ezema, F. I. (2005). Optical characterization of chemical bath deposited bismuth oxyiodide (BiOI) thin films. Turkish Journal of Physics, 29(2), 105114.

28. Maina, S. (2013). The role of entrepreneurship education on job creation among youths in Nigeria. International Letters of Social and Humanistic Sciences, 15: 87-96.

29. Emeruwa C. O. (2005). Capacity building entrepreneurial development. Paper presented at FCE (T) Potiskum on ETF Capacity Building held on 13 th-25th.

30. Aiyeduso, A. O. (2004). Principles and methods of business and computer education. Enugu, Cheston Agency Ltd Pub. 